Sains Malaysiana 50(6)(2021): 1727-1744

http://doi.org/10.17576/jsm-2021-5006-19

\title{
Assessing the Potential of Bone Marrow Concentrate for Cartilage Repair and Regeneration in Animal Models: A Systemic Review
}

(Menilai Potensi Kepekatan Sumsum Tulang untuk Pembaikan dan Pembaharuan Tulang Rawan dalam Model Haiwan: Suatu Kajian Sistemik)

\author{
Nabillah AbD RadZaK, Malliga Raman Murali* \& Tunku Kamarul
}

\section{ABSTRACT}

Bone marrow concentrate (BMC) has been emerging as a promising regenerative source to accelerate cartilage regeneration in cartilage injuries and osteoarthritis. Though the number of stem cells in BMC is limited, BMC is rich in growth factors that promote stem cell differentiation and tissue regeneration. Despite of multiple reports available on the use of BMC for cartilage repair in humans and its use in clinical settings, only limited number of pre-clinical proof of concept studies have been reported in animal models. Hence, a systematic review focusing on the potential of BMC for the treatment of cartilage defect in animal models has been conducted. The systematic search of literature using three popular databases, ISI Web of Knowledge, PubMed and Scopus, were conducted without year restriction. Fifteen $(n=15)$ studies were found appropriate and included in this review. All of the included studies were of different animal models with cartilage defect. 13 out of 15 studies reported that the usage of BMC gave the best outcome compared to other treatment methods. Most of the findings provided good scoring on the tissue repair and the histological outcome. However, most of the BMC group outcomes did not give a significant difference when compared with other interventions such as the addition of platelet rich plasma, erythropoietin, hyaluronic acid, transforming growth factor, autologous tissue implant, genetic modification or scaffoldings. In conclusion, the published studies do suggest that BMC could provide a better cartilage repair. However, more preclinical studies are required to provide definitive conclusions.

Keywords: Animal study; bone marrow aspirate; bone marrow concentrate; cartilage; systematic review

ABSTRAK

Konsentrasi sumsum tulang (BMC) telah muncul sebagai sumber penjanaan semula yang berpotensi untuk mempercepatkan pertumbuhan tulang rawan dalam kecederaan rawan dan osteoartritis. Walaupun jumlah sel stem di BMC adalah terhad, BMC kaya dengan faktor pertumbuhan yang membantu dalam proses pembezaan sel stem dan penjanaan semula tisu. Walaupun terdapat banyak laporan mengenai penggunaan BMC untuk pembaikan tulang rawan pada manusia dan penggunaannya dalam tetapan klinikal, hanya sebilangan kecil bukti kajian konsep pra-klinikal yang terhad telah dilaporkan dalam model haiwan. Oleh itu, semakan sistematikyang menumpukan kepada potensi BMC untuk rawatan kecacatan tulang rawan dalam model haiwan telah dijalankan. Pencarian sastera sistematik menggunakan tiga pangkalan data popular, ISI Web of Knowledge, PubMed dan Scopus, telah dijalankan tanpa pembatasan tahun. Sebanyak lima belas $(n=15)$ kajian didapati bersesuaian dan disertakan dalam kajian ini. Semua kajian yang terpilih termasuk model haiwan yang berbeza dengan kecacatan tulang rawan. 13 daripada 15 kajian melaporkan bahawa penggunaan BMC memberi hasil yang terbaik berbanding kaedah rawatan lain. Kebanyakan penemuan memberikan skor yang baik ke atas pembaikan tisu dan hasil histologi. Walau bagaimanapun, kebanyakan hasil kumpulan BMC tidak memberikan perbezaan yang signifikan jika dibandingkan dengan campur tangan lain seperti penambahan platelet kaya plasma, eritropoietin, asid hialuronik, mengubah faktor pertumbuhan, implan tisu autologous, pengubahsuaian genetik atau perancah. Kesimpulannya, kajian yang diterbitkan menunjukkan bahawa BMC dapat memberikan pembaikan rawan yang lebih baik. Walau bagaimanapun, lebih banyak kajian pra-klinikal diperlukan untuk memberikan kesimpulan yang pasti.

Kata kunci: Haiwan; konsentrasi sumsum aspirat; konsentrasi sumsum tulang; rawan; semakan sistematik 


\section{INTRODUCTION}

Bone marrow concentrate (BMC) also reported as bone marrow aspirate concentrate (BMAC) and concentrated bone marrow aspirate (CBMA) has been recently gaining its importance in the treatment of cartilage related diseases as it contains undifferentiated stem cells and growth factors which could be directly delivered via intra-articular injection at injury site. The usage of a minimally processed bone marrow concentrate (BMC) skips the lengthy and costly procedure of culturing methods, which then can be directly prepared and ready for use in the operating theatre, is fascinating. Number of studies has been reported on the use of bone marrow concentrate for cartilage repair. The potential of bone marrow is limitless due to its ability to provide stem cells that are capable of chondrogenesis and as source of growth factors that stimulates cartilage repair. It is believed to be having if not superior, equal to other cartilage repairing procedures (Huh et al. 2016; Madry et al. 2017). Another advantage of using the BMC is that chondro-progenitor cells in BMC will not lose their chondrogenic potential as the cultured cells during the in vitro monolayer expansion (Huh et al. 2016).

Despite of remarkable potential of BMC, there are also studies that challenge the previous opinions by highlighting the limitation of BMC. Due to the limited volume of chondrogenic niche in $\mathrm{BMC}$, it resulted in lack of stability of the repaired cartilage. The progenitor cells isolated from the density gradient only accounts for 0.001 to $0.01 \%$, however, a high concentration of growth factor including transforming growth factor-beta (TGF- $\beta$ ) and bone morphogenetic proteins 2 and 7 were reported (Chahla et al. 2016).

Prior to the administration of BMC into human use or clinical trials, extensive studies in animal models are essential. Hence, this review is intended to summarise the animal studies that have used the BMC for cartilage repair and regeneration. Limited studies have been done in animal model with the aid of other factors and materials throughout the years and to the best of our knowledge, there is no systematic review focusing on the studies of BMC for the treatment of cartilage defect in animal models. The purpose of this study was to conduct a systematic review focusing on the BMC potential for the treatment of cartilage defect in animal models.

\section{METHODS}

\section{SEARCH STRATEGY AND STUDY DESIGN}

The online databases used in this study include Scopus,
PubMed, and ISI Web of Knowledge. The search terms 'bone marrow concentrate' or 'bone marrow aspirate' and 'cartilage' were used, without any restriction to language and date of publication. These results were searched for studies matching the keywords and were reviewed thoroughly and individually. The bibliographies of relevant original research articles were searched for further studies. Searches on the available papers were included and concluded by July 2019 . The results of the selected articles reviewed here were critically scrutinized based on the treatment outputs such as tissue repair quality and study limitations. Results obtained were scrutinized and screened through to select the most related studies as shown in Figure 1.

\section{STUDY SELECTION}

All literature published up to July 2019, which was related to the usage of BMC alone or with other treatments and materials for cartilage repair in animal models, were selected. Studies were included whether the treatment group received BMC for any cartilage defect compared with another group receiving other cartilage repair treatments. Review papers and other studies that combined effects of BMC for other defects treatments such as bone or meniscus repair were excluded from further analysis.

\section{DATA EXTRACTION}

Data were extracted on: characteristics on selected studies; method of harvesting and processing BMC with the number of cells and delivery methods; quality of repaired tissue (gross morphology, histological, immunohistology and any other tests outcomes where available); limitation of each studies; and the summary outcomes. The outcomes measured involving descriptive data were also considered where possible.

\section{RESULTS}

\section{LITERATURE SEARCH AND SELECTION}

The online literature search using PubMed, Scopus, and Web of Science (ISI) found a total of 2474 scientific papers. After excluding duplicates, 1878 were reviewed for suitability and out of that, 1863 were excluded due to unrelated and irrelevant studies. Studies that were included were up to July 2019 and the remaining fifteen studies that speaks exclusively on the cartilage repair using bone marrow concentrate intervention were selected and reviewed in this paper. 


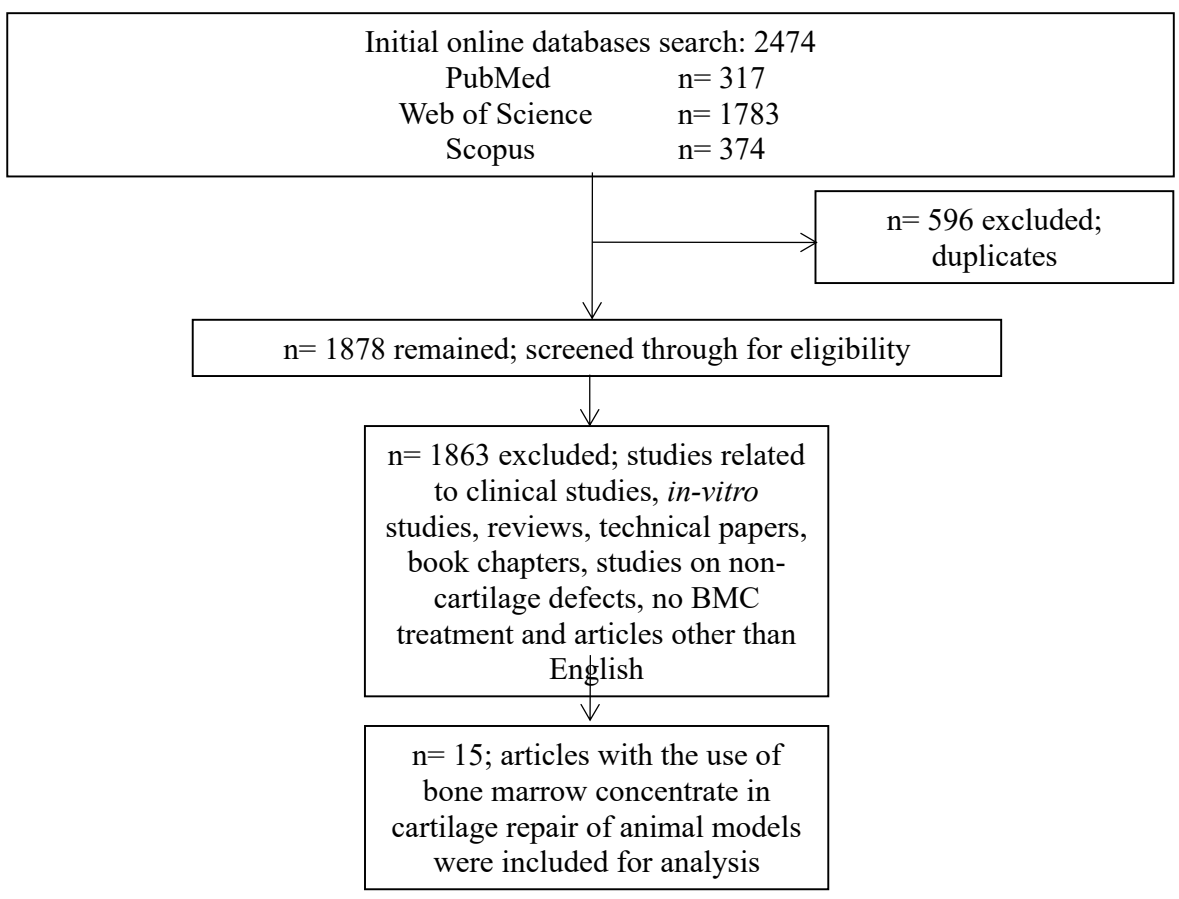

FIGURE 1. Inclusion and exclusion criteria flowchart selection process

\section{CHARACTERISTICS OF SELECTED STUDIES}

Studies included for this systemic review described the use of BMC in combination of other factors (EPO, TGF, PRP), techniques (microfracture) and material (HA, PGA, collagen, autologous tissue) to repair cartilage defects in animal models. Out of the fifteen studies; five were using rabbit model, three studies were on mini-pig, two were using horse, two studies on goat, two on sheep model and only one study is using beagle model. Out of fifteen, only two studies have reported the use of BMC independently while comparing with other treatment groups, whilst the other thirteen reports combined the BMC with other treatment methods. Most of the studies have assessed the therapeutic potential of BMC within 2 to 6 months. However, the shortest study period was 1.5 months (Veronesi et al. 2015) and the longest was 12 months (Chu et al. 2018). The thickness of the articular cartilage varies between different species, therefore, depending on the animal species and location of defect, different diameters of defect ranging from 3 to $15 \mathrm{~mm}$ and 2 to 10 $\mathrm{mm}$ deep were created in the animals. The animals and size of defects created were as follows; three mini-pigs studies with defects sizes between 6 and $7 \mathrm{~mm}$ diameter, two goat studies defects were 4 and $5 \mathrm{~mm}$ diameter, two sheep studies size of defects were 5.8 and $6.2 \mathrm{~mm}$ diameter, five rabbit studies defects made were between 3 and $5 \mathrm{~mm}$ diameter, two horse studies with defect size of $15 \mathrm{~mm}$ and one beagle study with defect size of $6 \mathrm{~mm}$. The treatment or intervention selected for defects creation also vary between studies. 10 out of 15 studies combined BMC with different types of scaffolds (HA, PGA, Collagen or biphasic) along with factors and cells such as PRP, EPO, and bone marrowderived MSC (BM-MSC). Four studies were looking into individual or combination effect of microfracture with BMC (Bekkers et al. 2013; Chu et al. 2018; Fortier et al. 2010) and/or autologous osteochondral transplant (Jin et al. 2011); and one study by Ivkovic et al. (2010) was using the growth factor comparing with BMC treated group. Few studies were reported on the complications such as mortality, surgical site infection and replacement of animals during the initial phase of the study. 
BONE MARROW HARVESTING TECHNIQUE, OBTAINING CELLS AND DELIVERY METHOD

Most common site of bone marrow aspirate collection reported in these studies was from iliac crest, whilst one study has isolated bone marrow from the sternum Fortier et al. (2010), one from distal femur (Hernigou et al. 2018) and one study did not mention the location of aspirate (Chu et al. 2018). The volume of aspirated bone marrow varies inter and intra species; 3 (Ivkovic et al. 2010) to 20 (Getgood et al. 2012) mL from sheep, $4 \mathrm{~mL}$ (Jin et al. 2011; Zhao et al. 2013) to $6 \mathrm{~mL}$ (Hernigou et al. 2018; Veronesi et al. 2015) from rabbit, $20 \mathrm{~mL}$ from goat (Bekkers et al. 2013), 20 to $24 \mathrm{~mL}$ from mini-pig (Betsch et al. 2014, 2013; Jagodzinski et al. 2013) and $60 \mathrm{~mL}$ (Chu et al. 2018) to 70 $\mathrm{mL}$ from horse (Fortier et al. 2010).

Chu et al. (2018) and Fortier et al. (2010) utilized the SmartPReP® 2 Centrifuge System (Harvest Technology) and Getgood et al. (2012) used Lymphoprep System (AxisShield) in processing the BMA. Four studies processed the bone marrow with Ficoll density gradient system (Amersham Biosciences and Sigma) and another four processed with normal centrifugation machines. Bekkers et al. (2013) on the other hand isolated the mononuclear fraction pellet of the centrifuged BMA. Three authors utilized the Marrow Stim Concentration Kit (Biomet Biologics) obtaining 3 to $4 \mathrm{~mL}$ of BMC.

Ivkovic et al. (2010) did not process the aspirate and directly mixed it with viral particles for gene modification, and the mixture was allowed to clot at the defect area. The number of cells reported for each study differs in terms of types of cells and volume/concentration as well (Table 1). Nine studies did an open surgery and implanted the scaffold containing the cells directly onto the defect (Betsch et al. 2014, 2013; Getgood et al. 2012; Hernigou et al. 2018; Jagodzinski et al. 2013; Veronesi et al. 2018, 2015; Yoon et al. 2016; Zhao et al. 2013), three studies did an open surgery to directly pipetted or injected cells and scaffolds onto defects (Bekkers et al. 2013; Ivkovic et al. 2010; Jin et al. 2011), two studies delivered the sample using arthroscopy method onto defect (Fortier et al. 2010) and one study utilized the intra-articular injection method (Saw et al. 2009).

\section{COMPARISON OF OUTCOMES BASED ON DIFFERENT} METHODS OF TREATMENTS

There were many methods of outcome measured, included but not limited to assessment scores such as International Cartilage Repair Society (ICRS) scoring systems and Rudert scoring system for macroscopic evaluation and MRI, O’Driscoll score and Gill scoring system for histology evaluation. Few studies also included the mechanical testing analysis for the fabricated scaffolds for future improvements (Getgood et al. 2012; Ivkovic et al. 2010; Jagodzinski et al. 2013), TRAP analysis (Jagodzinski et al. 2013), computed tomography testing (Betsch et al. 2014), Micro-CT (Yoon et al. 2016) and magnetic image resonance (MRI) (Chu et al. 2018; Hernigou et al. 2018). Two out of the ten selected studies were by Betsch et al. $(2014,2013)$ groups and from the thorough analysis of both papers, these studies do not appear to be overlapping each other in terms of method of interventions or the outcomes. Therefore, both papers were included in the analysis. Summary of these outcomes were summarized in Table 2. From the available literature, we have found that up to $90 \%$ of the studies hypothesized that BMC provided enhanced repair of the cartilage defect with combination to additional factors, with the exception for studies by Chu et al. (2018) and Getgood et al. (2012). Three studies started off with characterization of the desired cell, MSCs, by using flow cytometry for surface markers detection. In a study by Fortier et al. (2010), the flow cytometry results only at a specific gated area (gate 5) were stained positive for CD 44, CD 29, and CD 172a and negative for both hematopoietic cell markers, CD 34 and CD 45. Studies by Betsch et al. $(2014,2013)$ groups on the other hand stained positive for CD 44 (>90\%), CD 14 (91.2\%), CD 90 (89\%), CD 45 (5.9\%) and CD $34(2.5 \%)$ in 2013 and positive staining for CD 44 (> 89.3\%), CD 14 (93.6\%), CD 90 (93\%), CD 45 (6.4\%), and CD 34 (2.1\%) in 2014. The numbers correspond to the percentage stained of all viable single cells.

All of the studies showed that the addition of BMC in combination of other materials enhanced the repair of cartilage tissue compared to the control and other treatment groups, except for studies by Chu et al. (2018) and Getgood et al. (2012). Gross morphology of the repaired tissue gave a variety of outcomes. In treatment groups combining with the BMC, positive outcomes were observed; smoother surface level of defect area with adjacent cartilage, better integration of scaffolds with the surrounding tissue and better filling of the cartilage tissue in the defects. No lesions or inflammations were reported in any of the studies and none of the implanted scaffolds dislodged from the defect area. However, in few of the studies, fibrous cyst (Getgood et al. 2012; Jagodzinski et al. 2013) and subchondral bone cyst (Betsch et al. 2014, 2013) were found in control as well as treatment groups. Details of these findings were summarized in Table 2.

Majority of the studies produced a hyaline or hyaline-like cartilage tissue when combining BMC with additional interventions into their respective treatment 
groups. In few studies, the hyaline or hyaline-like cartilage also showed a columnar cluster organization of chondrocytes (Ivkovic et al. 2010). Microscopic view on most control cells observed disordered arrangement of fibrous-like cartilage tissue or mixture of both hyaline- and fibrous-like tissues in some cases. Scar tissues were also visible in most of the control groups. Groups that received any other interventions for defect treatment expressed little to strong staining of collagen type II and/or collagen Type I. Most BMC treatment groups showed intense staining of collagen type II and/or collagen type I. Getgood et al. (2012) was the only study reported that PRP gave the strongest expression of collagen type II with mild collagen type I expression compared to BMC.

Other methods of testing for the quality of repaired cartilage tissue were biomechanical testing of the implanted scaffolds and chondrogenic gene expression of the repaired tissue. In a study by Ivkovic et al. (2010), they found that the BMC treated group gave a similar stiffness of repaired tissue to native cartilage. It was even stiffness was even higher in the modified BMC group (BMC+TGF/BMC+GFP). Jagodzinski et al. (2013) also reported a significant difference in Young's modulus (elasticity) between all BMC treatment groups when compared with control group. Additional TRAP staining was also conducted where no significant differences in number of osteoclasts were found between all groups. Study by Zhao et al. (2013) reported a high expression of three chondrogenic genes; collagen type II, aggrecan and Sox9 mRNAs, in BMC treated group. Micro-CT study by Yoon et al. (2016) showed enhanced subchondral bone regeneration in BMC combination treated group. Magnetic resonance imaging (MRI) were conducted by two studies gave no significant difference between BMC and nonBMC treated groups (Chu et al. 2018; Hernigou et al. 2018). Details of the findings were summarized in Table 2.

TABLE 1. BM harvesting technique, BMC processing method, number and types of cells and the outcome

\begin{tabular}{cc}
\hline Author & BM harvesting \& concentrating \\
\hline Saw et al. (2009) & $\begin{array}{c}\text { Bone marrow harvested from bilateral iliac } \\
\text { crest and centrifuged at } 1,900 \mathrm{rpm} \text { for } 10 \mathrm{~min}\end{array}$ \\
Fortier et al. (2010) & $\sim 60 \mathrm{~mL}$ of bone marrow harvested from \\
the sternum and concentrated using \\
SmartPReP ${ }^{2} 2$ Centrifuge (Harvest \\
Technologies), obtaining $6 \mathrm{~mL} \mathrm{BMC}$
\end{tabular}

Ivkovic et al. (2010) $3 \mathrm{~mL}$ of bone marrow harvested from right

Jin et al. (2011)

Getgood et al. (2010)

Zhao et al. (2013) iliac crest

$\sim 4 \mathrm{~mL}$ of bone marrow harvested from iliac crest and concentrated using Ficoll gradient centrifugation system, obtaining $20 \mu \mathrm{L}$ of BMC

$\sim 20 \mathrm{~mL}$ of bone marrow harvested from the posterior iliac crests density gradient medium and concentrated by dilution with $20 \mathrm{~mL}$ of PBS and layered onto Lymphoprep (AxisShield, Oslo, Norway), centrifuged at $900 \mathrm{~g}$ for $20 \mathrm{~min}$. Buffy layer was removed, and a cell pellet produced via further centrifugation at $750 \mathrm{~g}$ for $10 \mathrm{~min}$

$\sim 4 \mathrm{~mL}$ bone marrow samples from iliac crest were concentrated by centrifugation in a Ficoll gradient (Sigma) at $1,500 \mathrm{rpm}$ for 10 min, obtaining $40 \mu \mathrm{L}$ of concentrate
Types \& number of cells (mean/range)

Mean total nucleated cell,

$220 \times 10^{6}$ cells and range

from 159 to $438 \times 10^{6}$ cells

Arthroscopy, directly

injected onto defect

MNC: $9.2 \pm 3.9 \times 10^{6}$ cells

and MSCs: $607.8 \pm 175.98$ cells $/ \mathrm{mL}$

Total nucleated cell: 0.25 to $6.87 \times 10^{9} / \mathrm{L}$

Open surgery, contained in scaffold

MNC: 0.1 to $3.45 \times 10^{9} / \mathrm{L}$

Open surgery, directly pipetted onto defect

Open surgery, directly injected onto defect

Average number of: MSC in BMS: $26.3 \pm 6.0$

Open surgery, contained in scaffold

MSC in HIC: $27.6 \pm 6.5$

$\mathrm{MSCs} / 40 \mu \mathrm{L}$ 
Bekkers et al. (2013) $\sim 20 \mathrm{~mL}$ bone marrow harvested from the iliac crest and concentrated at $300 \mathrm{~g}$ for 10 min and cell pellet collected and diluted in red blood cell lysis buffer (Sigma, The Netherlands). Cells spun down and wash with PBS, producing MNF fraction

Betsch et al. (2013) $\quad \sim 24 \mathrm{~mL}$ of bone marrow harvested from the iliac crest and concentrated using point-ofcare device (MarrowStim mini concentration system, Biomet Biologics, Inc., USA), obtaining 3-4 $\mathrm{mL} \mathrm{BMC}$

Jagodzinski et al. (2013)

Betsch et al. (2014)

Veronesi et al. (2015)

Yoon et al. (2016)

Chu et al. (2018)

Hernigou et al. (2018)

Veronesi et al. (2018)
$6.0 \pm 1.5 \mathrm{~mL}$ of bone marrow harvested from posterior iliac crest of each animal and concentrated using Ficoll-Paque (density $1.083 \mathrm{~g} / \mathrm{mL}$ ) (Sigma-Aldrich, Milan Italy) centrifugation system at $600 \mathrm{~g}$ for $30 \mathrm{~min}$ $24 \mathrm{~mL}$ of bone marrow aspirate harvested from iliac crest and centrifuged for $15 \mathrm{~min}$ at $2977 \mathrm{~g}$, and red blood cells were then selectively lysed using the ACK lysing buffer (Gibco), obtaining $0.3 \mathrm{~mL}$ of BMC $60 \mathrm{~mL}$ of BMA harvested and processed using SmartPReP® 2 BMAC (Harvest

Technologies) according to the manufacturer's protocol

$6 \mathrm{~mL}$ bone marrow sample harvested from internal condyle of the contralateral distal femur and layered onto $4 \mathrm{~mL}$ Ficoll-Hypaque solution $\left(1.077 \mathrm{~g} / \mathrm{cm}^{3}\right)$, undergo double centrifugation; obtaining BMAC pellet dissolved with $0.25 \mathrm{~mL}$ sterile PBS

$5.0 \pm 0.5 \mathrm{~mL}$ bone marrow aspirate harvested from posterior iliac crest of each animal and centrifuged $1000 \mathrm{rpm}$ for $10 \mathrm{~min}$

Open-surgery, direct

injected onto defect

Mean volume of $\mathrm{MNC}$ in:

Open surgery, contained in

a) BMAC: $23.08 \times 10^{6}$ scaffold

cells $/ \mathrm{mL} \pm 24.12$

b) PRP+BMAC: $43.85 \times$

$10^{6}$ cells $/ \mathrm{mL} \pm 43.00$

Mean of nucleated cells in

BMAC $10.7 \pm 2.6$ million/ $\mathrm{mL}$

Open surgery, contained in scaffold

Mean $\pm \mathrm{SD}$ of MNC in BMC:

a) BMAC $95.18 \times 10^{6}$ cells $/ \mathrm{mL} \pm 61.28$

b) EPO+BMAC $97.66 \times$ $10^{6}$ cells $/ \mathrm{mL} \pm 64.20$

$2.03 \times 10^{6}$ bone marrow mononuclear cells

Centrifugation

Mean total MNC: $9.66 \times$ $10^{9} \pm 2.37 \times 10^{9}$

Ficoll gradient

Mean total MNC: $7.32 \times$

$$
10^{8} \pm 3.35 \times 10^{8}
$$

Mean concentration of mononuclear cells: $21 \times 10^{6}$ cells $/ \mathrm{mL}$
Open surgery; contained in scaffold

Open surgery, contained in scaffold

Arthroscopy; BMC clotted using thrombin and applied directly onto defect

Open surgery, contained in scaffold

Open surgery, contained in scaffold

${ }^{a} \mathrm{BM}$, bone marrow; BMA, bone marrow aspirate; BMAC, bone marrow aspirate concentrate; EPO, erythropoietin; MNF, mononuclear fraction; PBS, phosphate buffer saline, BMS, bone marrow stimulation, MSC, mesenchymal stem cell; HIC, harvested iliac crest; PRP, plasma rich protein 
TABLE 2. Comparison of outcomes based on different methods (according to group of treatments)

\begin{tabular}{|c|c|c|c|c|c|}
\hline Author & Gross morphology & Histology & Immunohistology & Other testing & Outcomes \\
\hline \multirow{21}{*}{$\begin{array}{l}\text { Saw et al. } \\
(2009)\end{array}$} & a) Control \& & a) Control: scar tissue & a) Control: resence & - & Intra-articular \\
\hline & b) HA: semi- & present, disordered & of collagen type & & injections HA \\
\hline & transparent tissue, & arrangement of fibroblasts, & I and absence for & & with BMA gave \\
\hline & recognizable & proteoglycans absent & collagen type II & & better cartilage \\
\hline & margins, irregular & b) HA: less visible scar & & & repair, assessed \\
\hline & surface & tissue, hyaline-like & b) HA: type I & & histologically \\
\hline & & cartilage at interface & collagen less & & \\
\hline & b) HA+BMA: & with subchondral bone & visible, light & & \\
\hline & coverage almost & and adjacent to normal & staining type II & & \\
\hline & complete, surfaces & cartilage at the defect & collagen around & & \\
\hline & smooth and level & margins, proteoglycans & areas of hyaline-like & & \\
\hline & with normal & only at base and sides & cartilage & & \\
\hline & cartilage & of defect in the same & & & \\
\hline & & distribution as hyaline like & c) HA+BMA: type & & \\
\hline & & cartilage & I collagen staining & & \\
\hline & & c) HA+BMA: & found only in the & & \\
\hline & & chondrogenesis with & perichondrium & & \\
\hline & & hyaline cartilage & deeper cartilage & & \\
\hline & & formation, proteoglycan & stained strongly for & & \\
\hline & & accumulation in the deeper & type II collagen & & \\
\hline & & layers & & & \\
\hline
\end{tabular}

Fortier et al. BMC $+\mathrm{MF}$ : thicker, Increased proteoglycan (2010)

Ivkovic et al. (2010) more hyaline-

appearing repair tissue and better

integrated

MF: full-thickness fissures radiating from the periphery of the defect and the lack of fill in the proximalmedial $1 / 4$ of the defect were still visible repair tissue of $\mathrm{BMC}+\mathrm{MF}$ staining primarily located in the deeper layers than superficial layers of the compared to $\mathrm{MF}$

a) No treatment: acellular tissue within the defect with intact calcified layer and subchondral bone

b) BMClot: defect fill with fibrocartilage, clear demarcation between native hyaline and fibrocartilage, separated by a defect gap
Type-II collagen expressed greater in $\mathrm{BMC}+\mathrm{MF}$ group than in MF group. Bottom $50 \%$ or more of the repair tissue positive for type-II collagen in $\mathrm{BMC}+\mathrm{MF}$ group but only the very lowest layer expressed type-II collagen in MF

\section{GAG analysis: no significant difference between mean values of repaired cartilage in the treatment groups and native cartilage from contra-lateral knees}

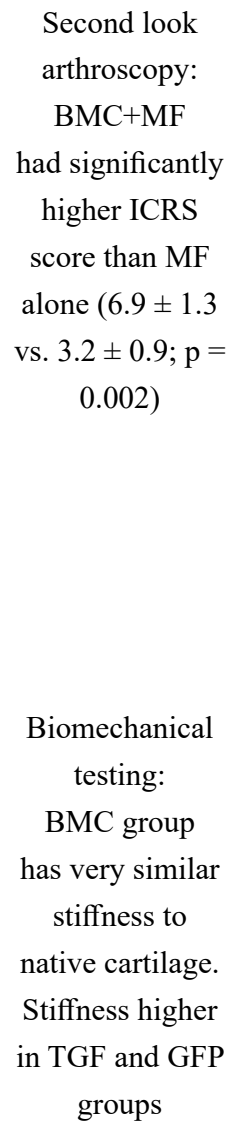

$\mathrm{BMC}+\mathrm{MF}$ result

in healing of acute full-thickness cartilage defects that is superior to

MF alone
Genetically modified bone marrow clots are sufficient to facilitate articular cartilage repair of partial thickness defects in vivo 
Jin et al.

(2011)

Getgood et

al. (2012)

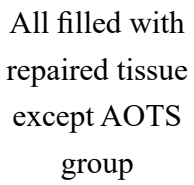

Increase in ICRS

score with the

scaffold + PRP

and scaffold +

CBMA groups

compared to the

empty defects and

scaffold alone,

but no statistically

significant

difference existed

between groups c) GFP: irregular filling, mixture of hyaline and fibrocartilage, clusters of clonal cell division present in upper layers

d) TGF: hyaline cartilage and columnar organization of chondrocytes detected on both sides of the defect gap

a) No treatment: fibrous tissue

b) AOTS: hyaline cartilage, no degeneration, graft tissue not integrated c) BMS: fibrous-like tissue d) BMS+BMC: well organized, intense ECM, columnar cluster cells, hyaline tissue
Increased O'Driscoll score noted in the scaffold +PRP group compared to the other 3 treatment groups, particularly in the MFC, not statistically significant

a) Empty defect, scaffold and scaffold + CBMA

defects: thickness of cartilage repair tissue less than thickness of normal adjacent cartilage.

b) scaffold + PRP defects: cartilage thickness restored to nearly normal

$$
\begin{array}{cc}
\text { Collagen type } & \text { Stiffness } \\
\text { I: significantly } & \text { significantly } \\
\text { higher in all } & \text { higher in GFP } \\
\text { treatment groups } & \text { group than in } \\
\text { compared with } & \text { TGF group }
\end{array}
$$

native cartilage, but

content in BMC

significantly lower

from than in GFP

and TGF groups

Collagen type II:

significantly lower

in BMC and GFP

treatment groups

when compared

with native cartilage

$$
\text { GAG in }
$$

$\mathrm{BMS}+\mathrm{BMC}$

significantly higher than in control and

BMS groups, but not as much as in the AOTS and Normal groups No statistically significant difference in the amount of GAG in the Buffy coat group, AOTS group, and normal cartilage

a) Empty defect: type I collagen staining with no pericellular type VI collagen staining and little type II collagen staining, indicating a fibrocartilage tissue

b) scaffold only: both type I and II collagen staining with pericellular type VI staining in the lateral margins, indicating whereas BMC

had lower

compared with

both GFP and

TGF
Biomechanical testing: All treatment groups in the MFC and LTS found to have similar mean stiffness compared to the contralateral limb and perilesional cartilage measurements
$\mathrm{BMS}+\mathrm{BMC}$

cartilage repair better than BMS alone
Scaffold + PRP produce repair tissue with more characteristics of hyaline cartilage. CBMA combined with collagenGAG biphasic scaffold shows no benefit over an empty $5.8-\mathrm{mm}$ osteochondral defect or a defect filled with scaffold alone apart from a reduction in subchondral cyst formation 


$$
\begin{gathered}
\text { Reduction at both sides } \\
\text { in appearance of residual } \\
\text { scaffold in scaffold }+ \\
\text { CBMA group compared to } \\
\text { other groups. Cysts only } \\
\text { detected in control and } \\
\text { control + scaffold groups; } \\
22 \% \text { of sections from the } \\
\text { empty or scaffold only } \\
\text { groups had cysts compared } \\
\text { to none in scaffold }+ \\
\text { PRP or scaffold + CBMA } \\
\text { groups }
\end{gathered}
$$

Zhao et al.

a) untreated group:

$$
\begin{aligned}
& \text { partially empty or } \\
& \text { concave, and some } \\
& \text { regenerated tissue }
\end{aligned}
$$

$$
\text { observed in }
$$

peripheral regions

b) BMS and PGA:

filled with whitish repaired tissue that appeared distinguishable from surrounding cartilage

c) BMC: filled with glossy white repaired tissue appeared to be smooth and well-integrated with a) Empty defects: proteoglycan staining in repair tissue in all MFC empty defects and relatively poor staining in the LTS empty defects

b) Scaffold only and scaffold + CBMA: moderate staining in all sections

c) Scaffold + PRP sections: strong staining, indicating high proteoglycan content within the repair tissue

a mixed hyaline/ fibrocartilage repair c) scaffold+CBMA: both LTS and MFC showed good type

II collagen staining and reduced type

I collagen staining compared to the scaffold only treatments, with

pericellular type VI collagen present at the margins of the MFC defect

d) Scaffold + PRP defects: strong type II collagen staining with mild type I staining. In MFC defect, pericellular type VI collagen detected throughout the repair zone

a) untreated: faint toluidine blue staining observed in margin areas adjacent to native cartilage

b) BMS: mixture of fibrous tissue and cartilage-like tissue, as shown by HE and toluidine blue staining but graft tissue not integrated with host tissue

c) PGA: relatively smooth surface, weak toluidine blue staining of regenerated fibrous-like tissue

d) BMC: filled with wellorganized tissue, regular surface and well-integrated with native cartilage.

Composed of columnar and cluster cells with hyaline character

\section{staining: each}

group essentially

equivalent to

toluidine blue

staining regions.

Intensively stained

collagen tissues

discovered in both

$\mathrm{BMC}$ and BME

groups

However, there was a trend toward increasing stiffness seen in empty defects in both LTS and MFC

Lower DNA

content detected

in BMC group

than in other

groups, and

no significant

difference

between PGA

and BMS groups
Combination of

BMC and PGA

scaffold can

supplement

BMS in rabbit

articular cartilage

repair. 


\author{
surrounding \\ tissues, remained \\ slightly \\ concave in the \\ centre \\ d) BME: smooth \\ and whitish, \\ repairing effect \\ similar to BMC \\ group in the \\ macroscopic view
}

$$
\text { e) BME: plenty of }
$$

chondro-like cells and

ECM, integration between

implanted tissue and host

tissue

observed, although not so

smooth

(n)

Bekkers et al. MF group showed (2013)

Betsch et al.

$$
\begin{gathered}
\text { less defect fill } \\
\text { at } 6 \text { months } \\
\text { compared to } \\
\text { chondrocyteMNF } \\
\text { group }
\end{gathered}
$$

No differences in

scores between

the two groups of

the femur cartilage

$$
\text { surface }
$$

Post-treatment

macroscopic scores

of the articulating

tibia cartilage

statistically

significantly higher

$$
\text { in }
$$

MF-treated defects

$$
\text { compared to }
$$

chondrocyteMNF

treated defects

$$
\begin{gathered}
\text { No lesions on } \\
\text { corresponding } \\
\text { articular } \\
\text { surfaces and no } \\
\text { inflammation } \\
\text { of synovial } \\
\text { membrane. None } \\
\text { of the } 28 \text { implanted } \\
\text { scaffolds dislodged }
\end{gathered}
$$

c) GAG: BMC group significantly higher than in the first three groups, and no statistically significant

difference

between amounts of

GAG in PGA and BMS groups

GAG production per gram of regenerated tissue did not show statistically significant

differences between two treatments $(25.61 \pm 14.95 \mathrm{mg}$ GAG per gram tissue vs $23.51 \pm$ $6.82 \mathrm{mg} \mathrm{GAG}$ per gram tissue for MF and chondrocyteMNF)

Newly formed tissue in cartilage area of defects in therapy groups stained blue with toluidine blue and contained collagen II based on positive immunostaining
Real-time PCR: revealed that levels of collagen II, aggrecan and Sox9 mRNAs, the three chondrogenic genes, were higher in both BMS and HIC groups than in control group. No differences in chondrogenic gene expression between BMS and HIC groups

Treatment using a combination of MNF cells from bone marrow and unexpanded chondrocytes leads to statistical significantly higher macroscopic regeneration scores compared to MF

\author{
Addition of PRP or \\ BMAC to biphasic \\ scaffold led to \\ better healing of \\ osteochondral \\ defects compared \\ control group, but \\ combination of \\ both therapies did \\ not further enhance \\ healing
}


Jagodzinski

et al. (2013)

Betsch et al

\begin{abstract}
a) Empty defect:
4/5 healed with remaining fibrous cyst without trabecular bone

b) Upside-

down cylinders:

remaining bone

defect found in $3 / 5$

animals

c) Scaffold \&

Scaffold+BMCC:

defects healed with

reconstruction

of underlying

subchondral bone

plate
\end{abstract}

\begin{abstract}
i) No abrasions
on opposing

articulating

surfaces
\end{abstract}

ii) No

inflammation

of synovial

membrane or

other joint tissues.

iii) No dislodged scaffolds

iv) Repaired tissue well integrated

with native

cartilage in therapy

groups

$$
\begin{aligned}
& \text { Repair tissue in bony } \\
& \text { phase fibrous with } \\
& \text { vascularisation and giant } \\
& \text { cells, indicating on-going } \\
& \text { degradation process of } \\
& \text { scaffold at } 26 \text { weeks. } \\
& \text { In } 10 \text { out of } 28 \text { defects, } \\
& \text { subchondral cyst noted in } \\
& \text { subchondral layer }
\end{aligned}
$$

a) Empty defect: Gradual

change from central fibrous

tissue to fibrocartilage

in $3 / 5$ specimens and

no transition zone into

surrounding healthy

hyaline cartilage

b) Upside-down cylinders:

Hyaline cartilage

formation found on

overgrowing edges of

$$
\text { defect }
$$

c) Scaffold \&

Scaffold+BMCC:

transition zone from the

regenerate with varying

amounts of fibrocartilage

into surrounding hyaline

$$
\text { cartilage }
$$

a) Therapy groups: positive staining of toluidine blue for chondrogenic tissue

b) Control: repaired tissue generally fibrous, deficient

$$
\text { in } \mathrm{SGAG}
$$

c) Residual scaffolds consistently found in

osseous phase of defects

after 26 weeks. ECM

of repair tissue in bony

phase was vascularised but

disorganized, occurrence

of foreign-body giant cells,

indicates that process of

scaffold degradation still

on going after 26 weeks.

In 9 defects, subchondral

bone cyst found in area

around the incompletely

resorbed scaffold
Mostly fibrous

tissue found in

defects of control

group, which

did not stain for

collagen type

II or sulphated

glycosaminoglycans

(sGAG)

Positive staining for

type II collagen in

Scaffold \& Scaffold

+ BMCC groups

when compared

with negative

stained controls

TRAP staining:
no significant
difference in
number of
osteoclasts

Filling of

osteochondral

defects with

porous scaffold

and with addition

between groups

of BMCC

decreases defect

Mechanical size compared

testing: with autologous

significant

difference in

Young's modulus

between all

experimental

groups and

controls

a) Therapy groups:

Cone-beam

positive staining for

collagen II

b) Control: fibrous

tissue, deficient in

collagen type II

computed

tomography of

a representative

medial femoral

condyle

delineated a

cystic radiolucent

area, which

smaller than

originally

cylindrical

repair area,

indicating that

bone adjacent

to implanted

scaffold began to

remodel starting

from edges of

defect
EPO+BMAC

enhanced

osteochondral

healing 
Veronesi et

al. (2015)

a) Scaffold only:

a) Scaffold only:

Fibrocartilage and poor

rough brown

fibrous tissue,

slightly empty in the centre

b) Scaffold/

BMC: Translucent

with high degree

of filling and

integration

c) Scaffold/PEMF:

Irregularity in

well-integrated

surface, filled up to

adjacent tissue

e) Scaffold/BMC/

PEMF fully filled

with integrated

and transparent

cartilage-like tissue

(indistinguishable

from normal

adjacent tissue)

Yoon et al.

a) IL8-scaffold,

BMC-scaffold \&

MSC-scaffold:

Incomplete

regeneration but

better than PBS-

scaffold group

c) IL8/BMC-

scaffold: Defect

almost entirely

regenerated

Chu et al.

Arthroscopy

morphology

BMC: 6 of 7

horses have $50 \%$

defect filled

Microfracture: 5 of

7 horses have $50 \%$

defect filled
GAG staining with altered cell distribution

b) Scaffold/BMC:

Fibrocartilage with normal cell distribution

c) Scaffold/PEMF: Mix of hyaline and fibrocartilage, moderate matrix staining, clusters of chondrocytes in few zones

d) Scaffold/BMC/PEMF:

Hyaline cartilage with

normal GAG content,

smooth surface and normal

chondrocytes distributions.

Bone reconstruction complete

\section{H\&E Staining: IL-8/}

BMC group showed

chondrocyte-like cells with

smooth cartilage-like tissue

compared to other groups

MT Staining: Higher

collagen content in IL-8/

BMC group

Safranin-O Staining:

Increase in GAG synthesis

in IL-8/BMC and IL-8

groups

Microfracture and

BMC group both gave

a similar in fibrous

tissue regeneration. No

significant difference

between ICRS scores of

both group

\section{Only IL-8/BMC \\ group induced \\ the expression of \\ type II collagen \\ and aggrecan \\ on regenerated \\ cartilage}

Micro-CT:
Subchondral
bone
regeneration
enhanced in IL-8

and IL-8/BMC

groups compared

to the control

\section{Morphological $\quad$ BMC application \\ \& Quantitative \\ MRI: BMC \\ group gave \\ better tissue \\ regeneration (4 \\ gave a similar \\ outcome to \\ microfracture \\ on critical-sized \\ defect}

of 7 horses) than

Microfracture

( 2 of 7 horses)

no significant

differences

between both

groups
Scaffold/BMC/

PEMF group gave better outcome

for osteochondral regeneration
Combination of

IL-8 and BMC

gave a significant enhanced impact on osteochondral regeneration 


\begin{tabular}{|c|c|c|c|c|c|}
\hline $\begin{array}{l}\text { Hernigou et } \\
\text { al. (2018) }\end{array}$ & $\begin{array}{l}\text { a) Control: Defect } \\
\text { visible, filled with } \\
\text { repaired white } \\
\text { tissue and nearly } \\
\text { completely present } \\
\text { at defect edge } \\
\text { b) Scaffold \& } \\
\text { Scaffold/BMMC: } \\
\text { Both edge and } \\
\text { bottom of defect } \\
\text { totally filled with } \\
\text { white hard and } \\
\text { translucent soft } \\
\text { tissue; close to } \\
\text { normal tissue level }\end{array}$ & $\begin{array}{l}\text { All defects fully filled with } \\
\text { cartilage tissue }\end{array}$ & $\begin{array}{c}\text { Control and } \\
\text { treatment } \\
\text { groups showed } \\
\text { heterogeneity of } \\
\text { tissue organization } \\
\text { with total or partial } \\
\text { differentiation in } \\
\text { hyaline cartilage, } \\
\text { with few producing } \\
\text { heterogenicity } \\
\text { of fibroblastic } \\
\text { and partially } \\
\text { differentiated } \\
\text { hyaline cartilage }\end{array}$ & $\begin{array}{l}\text { MRI: All groups } \\
\text { defect entirely } \\
\text { filled with } \\
\text { comparable } \\
\text { thickness and } \\
\text { signal of the } \\
\text { normal cartilage } \\
\text { surroundings }\end{array}$ & $\begin{array}{c}\text { Combination } \\
\text { of scaffold with } \\
\text { BMMC gave a } \\
\text { better outcome in } \\
\text { tissue regeneration } \\
\text { of cartilage lesion }\end{array}$ \\
\hline $\begin{array}{l}\text { Veronesi et } \\
\text { al. }(2018)\end{array}$ & & $\begin{array}{l}3 \text { months: All groups } \\
\text { except for SC + BMC } \\
\text { showed fibrous-tissue and } \\
\text { no hyaline-like cartilage } \\
\text { regeneration Formation of } \\
\text { subchondral bone in both } \\
\text { BMC's groups } \\
6 \text { months: SC+BMC } \\
\text { showed hyaline cartilage } \\
\text { formation while SC + } \\
\text { SN-BMC showed greater } \\
\text { cartilage organization }\end{array}$ & $\begin{array}{l}3 \text { months: } \\
\text { Untreated defect } \\
\text { group showed } \\
\text { higher collagen } \\
\text { I expression } \\
\text { compared to other } \\
\text { groups } \\
6 \text { months: } \\
\text { Untreated defect } \\
\text { group showed } \\
\text { higher collagen } \\
\text { I expression } \\
\text { compared to other } \\
\text { groups } \\
\text { Collagen II highly } \\
\text { expressed in SC } \\
\text { + BMC group } \\
\text { compared to } \\
\text { untreated defect }\end{array}$ & - & $\begin{array}{l}\text { BMC combination } \\
\text { groups gave } \\
\text { most successful } \\
\text { repair potential } \\
\text { for osteochondral } \\
\text { defect }\end{array}$ \\
\hline
\end{tabular}

${ }^{\alpha}$ ICRS, International Cartilage Repair Society; AOTS, autologous osteochondral transplantation; MF, microfracture; GFP, green fluorescent protein; TGF, transforming growth factor; AOTS, autologous osteochondral transplantation; ECM, extracellular matrix; BMC/BMCC/BMAC/; CBMA, concentrated bone marrow aspirate; BMS, bone marrow stimulation; GAG, glycosaminoglycan; FACS, Fluorescence-activated cell sorting; EPO, erythropoietin; SC, scaffold; SN, surnatants; MRI, magnetic resonance imaging; HA, hyaluronic acid; BMClot, bone marrow clot; BME, BMS together with composite of PGA and cultured bone marrow stem cells ; ChondrocyteMNF, chondrocyte mononuclear fraction; BMCC, bone marrow derived cell concentrate; EPO, erythropoietin; PEMF, pulse electromagnetic field 
TABLE 3. Limitations and future study suggestions (as observed and mentioned in the publication)

Studies

Saw et al. (2009)

Limitations and future study suggestions

a) Small sample size $(n=15)$ with the addition of animal death

b) No radiographic documentation of skeletal maturity

c) Lubricin and type $\mathrm{X}$ collagen staining with biomechanical testing of repaired tissue for high-quality hyaline cartilage should be done

d) Challenges in controlling post-surgery movement of animals i.e. passive motion and avoidance of weight bearing

e) Validation of results in skeletally mature animals with MA injections alone should be done f) Temporal progression study of repair process should be considered i.e. 1,2 and 4 months after surgery

Fortier et al.

a) Longer study period required for evaluation of durability of repaired tissue

(2010)

b) Acute cartilage defects were made in healthy joints and that does not reflect the relevance in human clinical diagnostics

c) No quantification of growth factors which could show strong correlation platelets and anabolic growth factors such as PDGF and TGF-b in platelet-rich plasma

d) Quantification of the exact number of cells in BMC necessary in relation to the quality of repaired tissue

Ivkovic et al.

Jin et al. (2011)

Getgood et al.

Zhao et al. (2013)

Bekkers et al.

Betsch et al.

Jagodzinski et al. (2013) a) Usage of a single factor to stimulate and regulate chondrogenic differentiation might limit the production of optimal quality

b) Challenges in controlling post-surgery movement of animals

a) No comparison of BMC group only to other treatment groups to study if the number of cells from BMC was overwhelmed by the microfracture

a) Variability in PRP obtained for application onto the scaffold

b) Small defect size which could be crucial to the repaired tissue and perilesional cartilage

c) Longer period of study needed to assess complete tissue healing for accurate comparison between groups

a) No control group using another scaffold for comparison purposes

b) No growth factors added for the proliferation and chondrogenic differentiation of MSCs

a) Incomplete defects fill in this study could have contributed to the slight to moderate degeneration seen after 6 months follow-up in treatments

b) Bilateral approach could also have added to the slight degeneration observed in both treatments at distant locations in the joint. This is important as most treatment failures or insufficient clinical improvement after cartilage therapy can be brought down to inadequate defect fill and tissue regeneration

c) Longer follow-up observation, up to 2 years should be considered for more definite and objective conclusions

a) Evaluation was done for osteochondral repair in acute, but not chronic mini-pig model. However, in clinical cases, human defects are usually of chronic nature. These differences should be considered when translating the findings in clinical settings

a) Longer follow-up of one year would have been desirable. Differences between the groups were small and are likely to have become smaller during further follow-up

b) Power of study should be done in determining the optimal sample sizes

c) Further characterization of heterogenic constructs on molecular level creates difficulties due to the wide range of regenerate quality within the defects

d) Limited value for clinical transfer due to model limitations and the surrounding tissue is mostly less favourable in a pathologic osteochondral defect

e) Defined cell numbers with different cell phenotypes are recommended for future studies 
Betsch et al.

Chu et al. (2018)

Hernigou et al. (2018)

Veronesi et al.

Yoon et al. (2016)

\section{DISCUSSION}

The major findings from the published studies in the selected articles that has been included this review do not appear to unanimously agree that the application of BMC provides the best repair outcomes for cartilage defect, ranging from good to excellent, compared to other intervention method. Although results and findings of these studies appear to be valid, there are very limited number of published animal studies and data relating to this subject matter (only 15 studies or publications were found to be relevant).

The analysed studies demonstrated a good effect for BMC in treating osteochondral defects, specifically the cartilage defects itself, most of which between 4 and $15 \mathrm{~mm}$ diameter and up to $10 \mathrm{~mm}$ deep. In the selected studies, BMC was used together with microfracture, microfracture, and scaffold or other additional factors. Most of the available animal studies have reported positive outcomes of using BMC in treating cartilage defect. The known composition of BMC are MSCs, hematopoietic stem cells, platelets, platelet derived growth factors and cytokines. In addition to that, the presence of antiinflammatory and immune-modulatory properties of bone marrow stem cells can also enhance tissue regeneration. MSCs present in the BMC is said to be the main player in improving the quality of cartilage repaired by increasing the aggrecan content and firmness of tissue (Sampson et al. 2013).

Even with the promising potential of BMC, the best isolation method to optimal concentration of $\mathrm{BMC}$ and the best possible way to deliver the BMC has yet to be reported. In addition to that, the components in BMC which are responsible to obtain the optimum cartilage repair remain a question. From the literature, it was understood that the percentage of progenitor cells in BMC, which is the MSCs, are very limited (Chahla et al. 2016) and it varies depending on the location and volume of harvested cells. The optimal number of nucleated cells injected or transferred coupled with the number of administrated dosages to the defects remains unanswered since all 
selected studies are using different animal models with varying defect sizes, locations, and treatments. Only a study by Saw et al. (2009) administered three injections of BMC and HA monthly to the treatment groups while the remaining fourteen studies were only administered once. The defect treatment outcomes gave almost the same outcome, good scar tissue recovery and the formation of hyaline cartilage for either once or three times of BMAC administered. A paper by Murphy et al. (2015) discussed on the importance of technique of bone marrow harvesting as the most important aspect in determining the optimum MSC concentration. The authors mentioned that large aspiration volumes from a single site give a significantly lower MSC concentration while smaller aspirates volume increased the nucleated cell counts and the CFU-F frequency of the nucleated cells (Murphy et al. 2015).

These limitations gave opportunity for more studies to be conducted to find the best possible method. This will then be able to close the gap between the current basic science knowledge and the application of it in clinical studies. Understanding the limitations of each study is important for future improvement by developing and modifying current methods in the hope to produce better outcomes.

Determining the optimal sample size is very important to obtain the best statistically possible outcomes of any study. Small number of samples may possible be one of the main limitations in most, if not all reviewed studies. In addition to that, the death or removal of infected or injured animals lowered the sample size that could possibly contribute to the insignificant statistical outcomes (Bekkers et al. 2013; Fortier et al. 2010; Getgood et al. 2012; Saw et al. 2009). Skeletal maturity study could also be done to match to the human skeletal matured system, to shorten the gap from animal study to clinical study (Saw et al. 2009). The challenges of using smaller animal models compared to larger animals, such as rabbits and mini pigs, with thinner layer of cartilage tissue with smaller defect size could induce spontaneous intrinsic healing, which findings could not be represented accordingly (Hernigou et al. 2018; Yoon et al. 2016).

Other than that, biomechanical study is also important to demonstrate that the repair tissue is of a high-quality hyaline cartilage which could withhold weight loading of the animals and eventually to translate it in human study. It was physically impossible to control the motion of animals after surgery to mimic human recovery period after the surgery, especially for quadrupeds which will naturally offload the operated knee until the pain is gone (Saw et al. 2009). Immediate weight bearing also might impeded the early phase of bone and cartilage regeneration and technically challenging and final proof of its efficacy in the cartilage repair of animals is still lacking (Betsch et al. 2014).

Only few studies from the selected papers conducted imaging analysis such as MRI and Micro-CT, which could benefit in giving additional information on the regeneration potential of osteochondral defect using the BMC combination treatment without being invasive. MRI can be used to observe the thickness of repaired cartilage in comparison to the adjacent normal cartilage. Apart from that, the integration of the repaired cartilage into its surroundings and its adhesion to the subchondral bone can also be observed (Chu et al. 2018; Henrigou et al. 2018). Micro-CT on the other hand focused more on analysing the subchondral bone layer condition of the repaired defect, the density of the underlying bone of the cartilage, and even abnormalities formed such as bone cyst/overgrowth formation (Yoon et al. 2016).

Short study period too, might not permit full observation for complete recovery of the defects, which therefore, might not give the most accurate outcomes comparable to studies that were conducted longer (Bekkers et al. 2014, 2013; Fortier et al. 2010; Jagodzinski et al. 2013). Variability in the sizes and locations of the defects according to the species could be an important factor for the tissue regeneration rate. If the defect were done on a nonload bearing area, the outcomes might be better compared to the one location at the weight-bearing area. Therefore, it could not give a clear outcome on the possibility of the knowledge transfer in clinical studies. The scoring systems of the treated tissue also vary between studies and it might have not reflected the actual comparison between studies and treatments. Details of the limitations were summarized in Table 3.

We recognize that this systematic review has its limitations. For the objectives of this review, major limitation of most studies was BMC was not used as a single mean of treatment comparing to other interventions. More studies on using BMC alone might have provided better understanding the use of BMC alone in cartilage repair and its superiority over other treatment methods, if any. For all animal models, evaluation was done in terms of the repair quality of the acute injury, not the chronic injury, which in most human cases chronic injury was more common. The defects were also created on healthy joints, which are not always the case in human injuries, 
which do not translate the real clinical symptoms. Due to the animal model limitations, such as different gait, weight-bearing capacity and weight-loading mechanism than human, the value for clinical transfer of the data are limited. Therefore, there is a gap which needs to be filled to ensure that in the future, these animal studies could be a platform of which the knowledge could be transferred to the clinical studies (Table 4).

TABLE 4. Summary from the systematic review

\begin{tabular}{|c|c|}
\hline Main point & Details \\
\hline \multirow[t]{6}{*}{ BMC harvesting techniques } & BMC isolation site: mainly from iliac crest \\
\hline & BMC volume harvested: varies between species; larger animal model provides more \\
\hline & volume compared to smaller animal models \\
\hline & Repair period: 2 to 6 months \\
\hline & Defect size and thickness: varies between species; larger animal models have larger \\
\hline & diameter and depth compared to smaller animal models \\
\hline \multirow[t]{2}{*}{ BMC processing methods } & Majority of the studies utilized commercialized kit in preparing the BMAC that adapted \\
\hline & the centrifugation-based method \\
\hline \multirow[t]{3}{*}{ Cells types used } & Majority of the studies reported the number of mononuclear cells from the BMAC \\
\hline & isolated, with no or less available data on mesenchymal stem cells or hematopoietic stem \\
\hline & cells \\
\hline Cells delivery method & Majority of the studies used the open surgery method \\
\hline Treatment groups & Majority of the studies combined BMAC with scaffolds \\
\hline \multirow[t]{5}{*}{ Outcomes } & Majority of the studies gave favorable outcomes in terms of the regeneration and quality \\
\hline & of the repaired tissue: \\
\hline & Hyaline or hyaline-like cartilage formation was observed \\
\hline & Gross-morphology: high scoring for the repaired tissue \\
\hline & Strong Collagen type II staining \\
\hline \multirow[t]{2}{*}{ Limitations } & Majority studies gave back the same limitations which are: long-term treatment period \\
\hline & needed for observing complete tissue repair \\
\hline
\end{tabular}

${ }^{\alpha} \mathrm{BM}$, bone marrow; BMA, bone marrow concentrate; BMAC, bone marrow aspirate concentrate

\section{CONCLUSION}

From this systematic review, the findings showed that bone marrow concentrate has potential in providing cartilage repair either alone or in combinations. Due to limitations of the currently available studies, the usage of larger animal models with uniformity in the defects created and the tests applied, concrete outcomes for cartilage repair and regeneration will able to be achieved. This will reduce the gap between the current applications of basic science in animal studies with the future clinical application of a one-step cartilage repair procedure in human.

\section{ACKNOWLEDGEMENTS}

The study was supported by the Malaysian Ministry of Higher Education, Transdisciplinary Research Grant Scheme (Grant No. TRGS/1/2016/UM/01/4/1).

\section{REFERENCES}

Bekkers, J.E., Creemers, L.B., Tsuchida, A.I., van Rijen, M.H., Custers, R.J., Dhert, W.J. \& Saris, D.B. 2013. One-stage focal cartilage defect treatment with bone marrow mononuclear cells and chondrocytes leads to better macroscopic cartilage regeneration compared to microfracture in goats. Osteoarthritis Cartilage 21(7): 950-956. 
Betsch, M., Thelen, S., Santak, L., Herten, M., Jungbluth, P., Miersch, D., Hakimi, M. \& Wild, M. 2014. The role of erythropoietin and bone marrow concentrate in the treatment of osteochondral defects in mini pigs. PLoS ONE 9(3): e92766.

Betsch, M., Schneppendahl, J., Thuns, S., Herten, M., Sager, M., Jungbluth, P., Hakimi, M. \& Wild, M. 2013. Bone marrow aspiration concentrate and platelet rich plasma for osteochondral repair in a porcine osteochondral defect model. PLoS ONE 8(8): e71602.

Chahla, J., Dean, C.S., Moatshe, G., Pascual-Garrido, C., Cruz, R.S. \& LaPrade, R.F. 2016. Concentrated bone marrow aspirate for the treatment of chondral injuries and osteoarthritis of the knee: A systematic review of outcomes. Orthopaedic Journal of Sports Medicine 4(1): 1-8.

Chu, C.R., Fortier, L.A., Williams, A., Payne, K.A., McCarrel, T.M., Bowers, M.E. \& Jaramillo, D. 2018. Minimally manipulated bone marrow concentrate compared with microfracture treatment of full-thickness chondral defects a one-year study in an equine model. The Journal of Bone and Joint Surgery 100(2): 138-146.

Fortier, L.A., Potter, H.G., Rickey, E.J., Schnabel, L.V., Foo, L.F., Chong, L.R., Stokol, T., Cheetham, J. \& Nixon, A.J. 2010. Concentrated bone marrow aspirate improves fullthickness cartilage repair compared with microfracture in the equine model. The Journal of Bone and Joint Surgery 92(10): 1927-1937.

Getgood, A., Henson, F., Skelton, C., Herrera, E., Brooks, R., Fortier, L.A. \& Rushton, N. 2012. The augmentation of a collagen/glycosaminoglycan biphasic osteochondral scaffold with platelet-rich plasma and concentrated bone marrow aspirate for osteochondral defect repair in sheep: A pilot study. Cartilage 3(4): 351-363.

Hernigou, J., Vertongen, P., Chahidi, E., Kyriakidis, T., Dehoux, J.P., Crutzen, M., Boutry, S., Larbanoix, L., Houben, S., Gaspard, N., Koulalis D. \& Rasschaert, J. 2018. International Orthopaedics 42(7): 1755-1767.

Huh, S.W., Shetty, A.A., Ahmad, S., Lee, D.H. \& Kim, S.J. 2016. Autologous bone-marrow mesenchymal cell induced chondrogenesis (MCIC). Journal of Clinical Orthopaedics and Trauma 7(3): 153-156.

Ivkovic, A., Pascher, A., Hudetz, D., Maticic, D., Jelic, M., Dickinson, S., Loparic, M. \& Pecina, M. 2010. Articular cartilage repair by genetically modified bone marrow aspirate in sheep. Gene Therapy 17(6): 779-789.

Jagodzinski, M., Liu, C., Guenther, D., Burssens, A., Petri, M., Abedian, R., Willbold, E., Krettek, C., Haasper, C. \& Witte, F. 2013. Bone marrow-derived cell concentrates have limited effects on osteochondral reconstructions in the mini pig. Tissue Engineering: Part C Methods 20(3): 215-226.

Jin, L.H., Choi, B.H., Kim, Y.J., Park, S.R., Jin, C.Z. \& Min, B.H. 2011. Implantation of bone marrow-derived buffy coat can supplement bone marrow stimulation for articular cartilage repair. Osteoarthritis and Cartilage 19(12): 1440-1448.
Madry, H., Gao, L., Eichler, H., Orth, P. \& Cucchiarini, M. 2017. Bone marrow aspirate concentrate-enhanced marrow stimulation of chondral defects. Stem Cells International 2013: 1609685.

Murphy, M.B., Terrazas, J.A. \& Buford, D.A. 2015. Bone marrow concentrate and platelet-rich plasma acquisition and preparation: Why technique matters. Technique in Regional Anaesthesia and Pain Management 19(1-2): 19-25.

Sampson, S., Bemden, A.B. \& Aufiero, D. 2013. Autologous bone marrow concentrate: Review and application of a novel intra-articular orthobiologic for cartilage disease. The Physician and Sports Medicine 41(3): 7-18.

Saw, K.Y., Hussin, P., Loke, S.C., Azam, M., Chen, H.C., Tay, Y.G., Low, S., Wallin, K.L. \& Ragavanaidu, K. 2009. Articular cartilage regeneration with autologous marrow aspirate and hyaluronic acid: An experimental study in a goat model. Arthroscopy: The Journal of Arthroscopic and Related Surgery 25(12): 1391-1400.

Veronesi, F., Desando, G., Fini, M., Parrilli, A., Lolli, R., Maglio, M., Martini, L., Giavaresi, G., Bartolotti, I., Grigolo, B. \& Sartori, M. 2018. Bone marrow concentrate and expanded mesenchymal stromal cell surnatants as cell-free approaches for the treatment of osteochondral defects in a preclinical animal model. International Orthopaedics 43(1): 25-34.

Veronesi, F., Cadossi, M., Giavaresi, G., Martini, L., Setti, S., Buda, R., Giannini, S. \& Fini, M. 2015. Pulsed electromagnetic fields combined with a collagenous scaffold and bone marrow concentrate enhance osteochondral regeneration: An in vivo study. BMC Musculoskeletal Disorders 16: 233.

Yoon, D.S., Lee, K.M., Kim, S.H., Kim, S.H., Jung, Y., Kim, S.H., Park, K.H., Choi, Y., Ryu, H.A., Choi, W.J. \& Lee, J.W. 2016. Synergistic action of IL-8 and bone marrow concentrate on cartilage regeneration through upregulation of chondrogenic transcription factors. Tissue Engineering Part A 22(3-4): 363-374.

Zhao, Q., Wang, S., Tian, J., Wang, L., Dong, S., Xia, T. \& Wu, Z. 2013. Combination of bone marrow concentrate and PGA scaffolds enhance bone marrow stimulation in rabbit articular cartilage repair. Journal of Materials Science: Materials in Medicine 24(3): 793-801.

Tissue Engineering Group

Department of Orthopaedic Surgery

NOCERAL, Faculty of Medicine

Universiti Malaya

50603 Kuala Lumpur, Federal Territory

Malaysia

*Corresponding author; email: drmurali@um.edu.my

Received: 21 February 2020

Accepted: 8 October 2020 